\title{
Corporate Social Responsibility Reporting through the Lens of ISO 26000: A Case of Malawian Quoted Companies
}

\author{
Andrew Munthopa Lipunga ${ }^{1}$ \\ ${ }^{1}$ Department of Accountancy, University of Malawi-The Polytechnic Blantyre, Malawi \\ Correspondence: Andrew Munthopa Lipunga, Department of Accountancy, University of Malawi-The \\ Polytechnic, Private Bag 303, Chichiri, Blantyre 3, Malawi. Tel: 999-694-031. E-mail: alipunga@ poly.ac.mw
}

Received: November 14, 2014

Accepted: December 17, 2014 Online Published: January 25, 2015

doi:10.5539/ibr.v8n2p28

URL: http://dx.doi.org/10.5539/ibr.v8n2p28

\begin{abstract}
The paper examines the status of corporate social responsibility (CSR) reporting in the annual reports of Malawian quoted companies through the lens of ISO 26000 - Guidance on social responsibility. The study used content analysis methodology. A CSR disclosure index was developed based on ISO 26000's seven core subjects of social responsibility to measure the level of CSR information disclosure in the annual reports for 2012 and 2013. The results indicate that all the sampled companies were making some CSR disclosures in their annual reports; however the disclosure levels are generally low. Out of the seven CSR themes, the companies scored highly only on organisational governance category and above average on community involvement and development and labour practices categories. On the other hand, they scored poorly on human rights, consumer issues, fair operating practices and environment categories. Furthermore, low individual company scores and the overall score suggest that much more effort is needed to enhance CSR reporting among Malawian quoted companies. The study seems to highlight that there is low awareness amongst the preparers of annual reports regarding all relevant categories that make up CSR. Thus the study recommends promotion of ISO 26000 among them in order to promote holistic approach to CSR that may lead to holistic CSR reporting.
\end{abstract}

Keywords: Corporate Social Responsibility (CSR), ISO 26000, Malawi, quoted companies

\section{Introduction}

Corporate social responsibility (CSR) can be defined as the responsibility that a company has towards all its stakeholders in earning profits (Lee, 2005). It is generally premised on the idea that companies should be concerned about stakeholders' expectations and not only about their own interests (Sitnikov \& Bocean, 2012). Thus Hayes and Ebinger (2011) explained that the "sense of social responsibility is the propensity of a company to undertake a project or action based on its contribution to the common good, even if financial considerations do not justify the spending based on the firm's goal of profit maximization". Furthermore, Ávila et al. (2013) noted that companies are expected to exercise "corporate social responsibility" on the understanding that they are social institutions existing only because society has authorised them to operate, to use resources-including from society itself - and to affect the quality of citizens' lives. It is now being recognised that organisations have a relationship with its stakeholders in order to enhance a positive contribution to society (Habidin et al., 2012). As such, CSR seeks to harmonise economic development and responsibility for the impacts that the development brings (Castka \& Balzarova, 2007) on the society at large.

The society now than ever is demanding greater transparency, accountability and responsibility from organisations (Institute of Directors of Malawi, 2010). Thus it is being acknowledged that CSR is an inclusive approach to the management of organisations, as it challenges the organisations to take an extra mile over and above the traditional obligations towards the shareholders. United Nations Environment Programme (2011) notes that the crucial aspect of CSR is in encouraging the companies not only to serve the traditional needs of shareholders, but also the needs of other stakeholders, including civil society groups, community leaders, customers, employees, government entities, international organizations, media, suppliers, trade unions, trustees, and future generations. Companies are now under pressure to engage in CSR activities.

Furthermore, the demand for transparency and accountability has also led to CSR reporting. Basically it is acknowledged that social responsibility is not new concept (Zhang, 2012), besides, Mbekomize and Wally-Dima (2013) indicates that even the need for social responsibility reporting has been there for over four decades. 
However, it is admitted that CSR reporting has received increasing attention with modern industry (Zhang, 2012). Mohammed et al. (2009) observed that the modern industry is facing ever-changing corporate environment that is increasing competitive pressures and making stakeholders (i.e. shareholders, investors, government and regulators) to demand more information from organisations not only on the financial aspects but also on non-financial issues. Thus, Mohammed et al. (2009) asserted that in order for the organisations to maintain competitiveness, they need to include social, environmental, corporate governance and stakeholders' concern into corporate strategy (Mohammed et al., 2009). Besides, they must be making relevant disclosures, as the availability of social responsibility information is assisting users in making more informed decisions about a company concern (Al-Khater \& Naser, 2003).

The paper endeavoured to evaluate the extent of CSR reporting by the Malawian quoted companies through the lens of ISO 26000. To the best of the knowledge of the researcher, there has not been any study on CSR reporting of Malawian listed companies or any empirical evaluation of extent of the adoption of the ISO 26000 in the country. The study provides empirical evidence of the degree of CSR reporting by the quoted companies and the status of the same in line with ISO 26000. The study serves as a reference point to policy makers in the promotion of CSR and CSR reporting and adoption of ISO 26000 framework in the country. Furthermore, it is acknowledged that much of the studies reporting on the CSR practices are carried in western countries, as a result, little is known of the same from developing countries (Gao, 2011). The study endeavours to provide empirical evidence of CSR practices from a developing country. The rest of the paper is structured as follows. Section two reviews the significance of CSR, the ISO 26000 framework and the Malawian CSR framework for the quoted companies. Section three discusses the research methodology used and section four presents the findings and the ensuing discussion. Finally section five gives concluding remarks.

\section{Literature Review}

\subsection{Significance of CSR to Organisations in the New Economy}

According to United Nations Environment Programme (2011) corporate social responsibility is generally understood to be a form of voluntary self-regulation by private enterprises, organizations, and other entities. Although in most countries CSR is generally voluntary, organisations are currently under increasing pressure due to public demand. Traditionally, CSR used to be thought of as involving merely donations or volunteerism, however going by the current CSR thinking; these are only a very small aspect (Lee, 2005). The concept is much broader with serious strategic implications. Yeung (2011) recognised that demand for accountability and transparency from both public and private sectors is soaring, as a result, organisations that are not concerned with the needs and expectations of the stakeholders will be uncompetitive in relation to those who do. Furthermore, Mohammed et al. (2009) observed that the corporate environment is currently very dynamic and very competitive that requires organisations to include social, environmental, corporate governance and stakeholders' concern into their corporate strategy in order to remain competitive. Generally, the current operating environment is radically different from the old; this is the reason why it is being referred as the new economy. Accordingly Smeureanu et al. (2011) highlighted that the new economy characterised by organizational interoperability, knowledge management, transparency, environment concern, efficient use of resources, among other things. As such Smeureanu et al. (2011) posited that it is not sufficient anymore to determine an organization's performance only by analysing the financial figures, emphasising that there is now a need to take into account a new classification criterion of "social responsibility". Basically, the work of an organization in relations with the local community and environmental impact has become a critical measure of its overall performance and ability to function effectively (International Organization for Standardization, 2010; Sitnikov \& Bocean, 2012).

Business organizations especially are expected to provide for and prove their accountability to the society associated with their profit maximisation motive in order to preserve the prolonged existence of the corporate image (Yeshmin, 2012). Sitnikov and Bocean (2012) indicated that the specific and important role of CSR is seen to be that of reconciling discrepancies arising between company profits and social goals. They explained that a CSR program enables managers to be aware of these conflicts and seriously managed the ensuing problems. This is why Lee (2005) noted that CSR is being seen as a way of doing business in a responsible way. In harmony, CAMAC (2006) also propagated the same view that CSR is about responsible business practices or in other words "business responsibility". Thus CSR in the broadest sense is being perceived as a comprehensive set of policies, practices, and programs that are integrated into business operations, supply chains, and decision making processes throughout the company and include responsibilities for current and past actions as well as adequate attention to future impacts (Masud, 2011). This is the reason organisations have no better option but to embrace CSR and incorporate it as an integral part of the corporate strategy (Lee, 2005; Sitnikov \& Bocean, 
2012).

Ávila et al. (2013) testified of how social responsibility, along with sustainability, is benefitting many companies that have embraced it in the areas of strategy, marketing, advertising, and publicity. In harmony, Karagiorgos (2010) reported also empirical evidence that suggested that adoption of CSR strategy enables the company to be evaluated positively by the market and its stakeholders. Furthermore, International Organization for Standardization (2010) acknowledged the pervasiveness of the influence of social responsibility. It stated that the perception and reality of an organization's performance on social responsibility can influence, among other things:

"competitive advantage, reputation, ability to attract and retain workers or members, customers, clients or users, maintenance of employees' morale, commitment and productivity, view of investors, owners, donors, sponsors and the financial community, relationship with companies, governments, the media, suppliers, peers, customers and the community in which it operates."

Thus, according to current thinking, CSR is not necessarily as a cost creation program; but a program that can create an instrument of added value (Hernáez et al., 2012). This explains why Tjia and Setiawati (2012) recounted that the social activities are no longer considered as a financial burden, but rather as "social capital investment". According to Abbasi et al. (2012), it may also be referred as "ethical investment" due to its positive impacts on organizations' wellbeing.

\subsection{Overview of ISO 26000 - Guidance on Social Responsibility}

ISO 26000 - Guidance on social responsibility is a standard issued by International Organization for Standardization (ISO) in 2010. The standard is as a result of a five-year negotiation process involving the international working group and national committees in over 90 countries (Ward, 2012). It was being truly argued that social responsibility nature of a company is a very complex feature requiring analysis that takes into account a wide variety of factors, actions and features (Smeureanu et al., 2011). As a result this makes it very difficult to fully-classify a company based on its social responsibility level by taking into account the complete list of factors (Smeureanu et al., 2011). This was a major challenge in the negotiation process for the standard. International Organization for Standardization (ISO) circumvented this challenge by bringing together all the important aspects of social responsibility however in form of a guidance standard. According, the key aspect of ISO 26000 is in establishing guiding principles as opposed to specifications for certification (Castka \& Balzarova, 2008). Thus no organisation would become ISO 26000 certified (Ward, 2012) as is the case with other standards. In other words the aim of ISO 26000 is not to define a system through a set of requirements (Castka \& Balzarova, 2007). ISO 26000 simply develops practical forms of social responsibility, framed to support organizations contributing to a continuously sustainable development (Zhang, 2012).

In ensuring that the standard represents the consensus of all stakeholders; Ward (2012) explained that participants within the negotiating process were divided into stakeholder groups spanning governments, non-governmental organisations (NGOs), businesses, trade unions and international organisations. Consequently the standard considers the impacts of all kinds of organisations both in public and private sector (Ward, 2012), in developed and developing countries (Smeureanu et al., 2011). Consequently, ISO 26000 is acknowledged as a globally harmonised pertinent guidance for private and public sector corporations of all types (Sitnikov \& Bocean, 2012). Castka and Balzarova (2008) asserted that ISO 26000 is truly a holistic standard as it encompasses the environment, social issues, health and safety, emission and many more. Besides, it is being applauded for making sustainable development the overarching goal of the concept of 'organisational social responsibility' (Ward, 2012).

Basically, the standard provides understanding of what social responsibility is and what is required to be done in order to operate in a socially responsible manner (Sitnikov \& Bocean, 2012). It provides a clear guide to organizations to integrate their financial interests together with environmental and social benefits when conducting daily operation (Zhang, 2012). According to International Organization for Standardization (2010), ISO 26000 addresses seven core subjects of social responsibility as portrayed in Figure 1. 


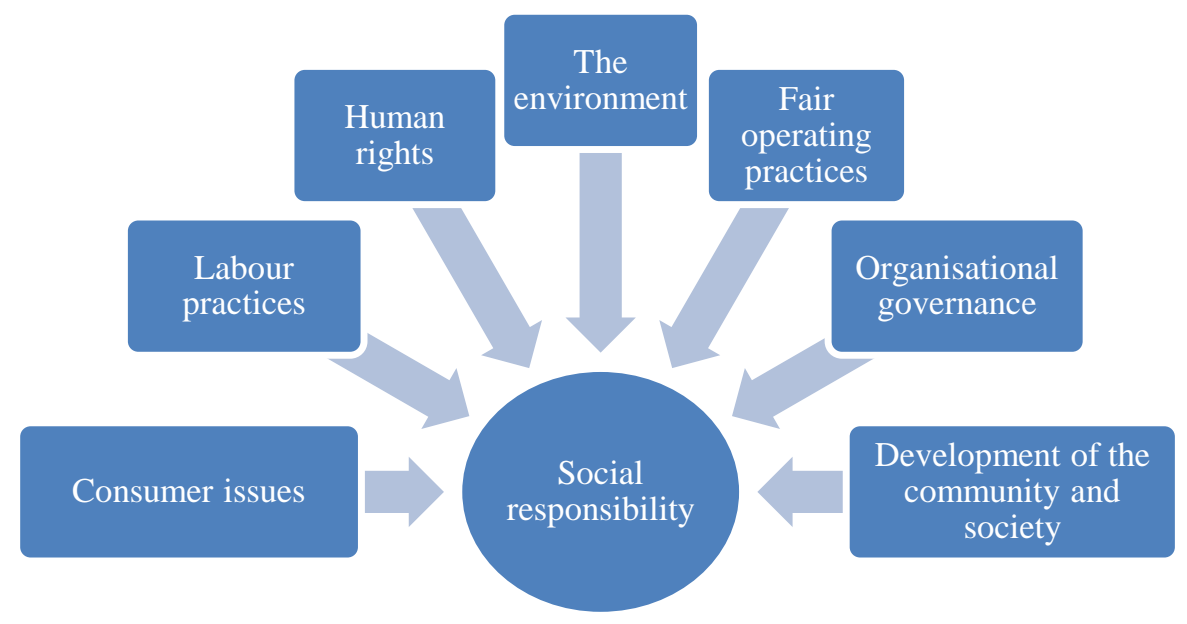

Figure 1. ISO 26000's seven core subjects of social responsibility

As exhibited in Figure 1, ISO 26000's seven core subjects of social responsibility include: customer issues, labour issues, human rights, the environment, fair operating practices, organisational governance and development of the community and society. Unlike other related standards such as ISO 9000, ISO 26000 is commended for taking much wider approach (Castka \& Balzarova, 2007). Castka and Balzarova (2007) explained that:

"Whereas ISO 9000 focuses at quality management systems and specification of the requirements for these, ISO 26000 discusses much broader issues in the field of social responsibility - such as social, environmental and legal diversity in the world and puts them in the perspective in terms of globalization, climate change, organisational governance or sustainable development - to name but a few. Building on these issues, ISO 26000 demonstrates how to understand and translate these issues into organisational settings. The focus is on stakeholders and society in large as opposed to predominantly customers (ISO 9000). As the social responsibility field is less defined and understood, ISO 26000 inevitably devotes more space to discussing and defining wider societal issues in comparison to ISO 9000."

ISO 26000 being simply a guidance standard, a number of useful benefits do accrue. They include the issue of flexibility in adoption since it is generally incumbent on individual organizations to consider the needs of their stakeholders in the seven aspects when designing work processes or executing business-related activities (Yeung, 2011). Thus it does not exert unnecessary compliance burden on the organisations. Furthermore, as opposed to pronouncements emblematic for the growing trend of regulation and intervention in business, ISO 26000 simply compiles the best practices developed by public and private initiatives (Sitnikov \& Bocean, 2012). Sitnikov and Bocean (2012) explains that ISO 26000 is not intended to impose mandatory regulations but to be an instrument of social responsibility that will be a help for companies that want to take account of stakeholder views to do it with ease. The intention of ISO 26000 may be summarised as:

"To encourage them [organisations] to go beyond legal compliance, recognizing that compliance with law is a fundamental duty of any organization and an essential part of their social responsibility. It is intended to promote common understanding in the field of social responsibility, and to complement other instruments and initiatives for social responsibility, not to replace them." (International Organization for Standardization, 2010).

Accordingly, it is acknowledged that ISO 26000 can be practically useful to organisations in the following three ways: (1) in providing a common language and framework for organisations; (2) in orienting their own policies; and (3) in using the listing of issue areas to report on key topics (United Nations Environment Programme, 2011).

\subsection{Review of the Malawian CSR Framework for Quoted Companies}

At the moment there is not specific law directly requiring CSR reporting by the companies in Malawi. Even the listing rules contain no direct provisions in relation to CSR reporting. However, the CSR framework for Malawian quoted companies can be derived from the applicable corporate governance code and guidelines 
namely: the Malawi Code II and the Corporate Governance Guidelines for banks issued by the Institute of Directors of Malawi and the Reserve Bank of Malawi respectively. Although the latter is specifically applicable to the banks only, it is significant to the study since four (28\%) of the fourteen Malawian quoted companies (see Table 1) Are banks. The following subsections discussions the CSR reporting provisions in each of them.

\subsubsection{The Malawi Code II}

The Malawi Code II comprise a set of "Overarching Provisions (OPs)" that apply to all organisations in Malawi and sector-specific guidelines that gives details of how the OPs applies in specific cases or specific types of organisations (Institute of Directors of Malawi, 2011). The OPs were issued in 2010 as voluntary (Institute of Directors of Malawi, 2010), however in relation to the listed companies, the "sector guidelines for listed companies" issued in 2011 made compliance with the OPs and the guidelines themselves mandatory for companies listed on Malawi Stock Exchange (Institute of Directors of Malawi, 2011). The Malawi Stock Exchange was as a result invited to be the main "custodian" of the sector guidelines for listed companies and to include compliance as part of its listing requirements (Institute of Directors of Malawi, 2011).

According to the OPs the aim of the code of corporate governance is to "establish an environment conducive to enabling organisations to grow, thrive, survive and create sustainable development for Malawi, whilst acting as good corporate citizens" (Institute of Directors of Malawi, 2010). The code comprehensively provides for what should constitute the organisational governance structure and specifies the roles of the constituents. It specifically requires the owners to ensure that their organizations act as a good corporate citizen and take into consideration the views of stakeholders. It further requires the board as part of its decision making process to take into consideration wider societal interests and other circumstances affecting how the organisation fulfils its "license to operate".

At the organisational level the code requires the organisations to act ethically. In so doing the organisations entreated to consider developing a Code of Ethics aimed at fostering an ethical culture within their organisation. In case where an organisation decides to adopt a code of ethics, the Malawi Code II requires that it should:

1) Commit the organisation to the highest standards of behaviour;

2) Be developed with the full participation of all parties expected to abide by it;

3) Receive total commitment from the Board and the Chief Executive Officer of the organisation;

4) Be sufficiently detailed as to give a clear guide to the expected standards of behaviour of all employees.

Besides, the Code expects organisations to adopt the African "umunthu" values within their ethical framework. Basically, according to Khomba and Vermaak (2012) "umunthu" or "ubunthu" may be translated as humanness. And can be described as "the capacity in an African culture to express compassion, reciprocity, dignity, humanity and mutuality in the interests of building and maintaining communities with justice and mutual caring" (Khomba \& Vermaak, 2012 citing Khoza, 2006; Luhabe, 2002; Mandela, 2006; Tutu, 1999). The "Umunthu" values recognise that the survival of a human being is dependent on other people, such as the community and society (Khomba \& Vermaak, 2012). In line with that understanding, the Malawi Code II explicitly provides that the relationships within the organisation and with its stakeholders must be guided by the concepts of thoroughly valuing others and ourselves, cooperation, kinship and sense of belonging within the community.

Furthermore the Malawi Code II incorporates "good citizenship" as one of its main topics. Under which the Code recognised that organisations as economic entities as well as citizens of Malawi have "a moral and social standing within Malawian society, with all the responsibilities attached to that status". As a result, when making decisions organisations should consider the impact of its decisions on its stakeholders (both internal and external), the environment and society as a whole. Further to that other main topic of interest is "sustainability". Under this topic the Code provides that organisations should conduct their operations in a manner that meets existing needs without compromising the ability of future generations to meet their needs. Accordingly organisations should be taking into account the impact that the organisations operations have on the environment, economic and social life of the community in which it operates including on its supply chain.

In terms of reporting, the Code recognises that current society demands greater transparency, accountability and responsibility from organisations. Consequently, the organisations should consider making regular, timely, balanced and understandable statements about their activities, performance and future prospects. Accordingly organisations are required to report specifically "on how they have both positively and negatively impacted on the environment and on the economic and social life of the community in which they operate and how they believe they can improve the positive and eradicate or lessen the negative aspects in the coming year". To ensure effective implementation, the code provides for sustainability reporting and disclosure which should be 
integrated within the organisation's financial reporting.

\subsubsection{The Corporate Governance Guidelines for Banks}

The corporate governance guidelines for the banks were issued in 2010 by the Reserve Bank of Malawi in pursuant to Sections 26 and 57 of the Banking Act, 1989 in lieu of a directive (Reserve Bank of Malawi, 2010). The introductory remarks of the guidelines explicitly recognise social responsibility as one of the principles of corporate governance within which banks must operate. Thus guidelines posited that for the banks, corporate governance process and structure should among other things establish mechanisms for achieving accountability and take into account the effects of processes on other stakeholders, such as creditors, employees, customers and the general community.

The guidelines also provide a comprehensive organisational governance structure with much detail relative to the Malawi Code II; however the roles of the owners in relation to social responsibility were not mentioned. Basically, the guidelines require the board to ensure that senior management implements strategic policies and procedures designed to promote good and acceptable ethical behaviour. Besides the board is to ensure that a policy is in place encourages employees to freely communicate concerns about illegal, unethical, unprofessional or questionable practices to the board or an independent committee thereof, as well as to senior management, without fear of reprisal. In addition, it requires that the whistleblowing include an option for employees to make their concerns known anonymously.

Furthermore the board is required to adopt a written code of ethics that sets out explicit expectations for ethical decision making and personal behaviour by all board members and employees with respect to conflicts of interest. In implementing these provisions the board is to ensure that the adopted code of ethics:

1) Includes measures for dealing with breaches of the code;

2) Is reviewed at least annually;

3) Has a system put in place by management to implement it and to report to the board on the record of compliance at least annually;

4) Is communicated to all employees by management and employee training is provided after every review.

Furthermore, the banks are required to publish the code of ethics and information is provided in the annual report about the steps taken to comply with the code of ethics, including any serious instances of unethical behaviour and any action(s) taken.

With respect to the stakeholders, the guidelines require the board to have clear written policies for the bank's relationships with significant stakeholders. The board is further required to regularly assess compliance with these policies to ensure that the conduct towards the stakeholders complies with the code of ethics and the law and it is within broadly accepted social, environmental, and ethical norms.

Finally with respect to CSR reporting, the guidelines require that in the annual report, the banks should provide both negative and positive information about the bank's corporate social responsibility and activities and how the bank has served the interest of their stakeholders. The information is to report on the nature and extent of the bank's social activities, ethical, safety, health and environmental management policies and practices.

\subsubsection{Theoretical Basis for the Malawian CSR Framework and It Relation to ISO 26000 Framework}

Generally the analysis above suggest that the CSR and CSR reporting is well recognised within corporate governance code and the guidelines. The review suggests that in relation to CSR, the Malawi Code II is premised on both legitimacy and stakeholder theories. On the other hand, the corporate governance guidelines for the banks seem to be so much rooted on the stakeholder theory. The legitimacy theory assumes the existence of social contract between entity and the society and that the entity takes actions to ensure that their behaviour is perceived as legitimate by the society (Khan \& Ali 2010). It is assumed that organisations tend to carry out CSR activities and reporting in order to fulfil the "license to operate" and to give testimony of its fulfilment. On the other hand the stakeholder theory postulates that firms have responsibility to broad spectrum of society which includes customers, employers, suppliers, community, government etc. and not merely to the shareholders (Akinpelu et al., 2013). As a result the organisations engage in CSR activities and CSR reporting in recognition of the demands of the stakeholders. Despite some difference in these two theories it is recognised that they are interrelated. While the stakeholder theory is built on the demands of stakeholders including employees, customers, community and the environment for companies to behave responsibly, the legitimacy theory's emphasis is based on showing a socially responsible image so as to legitimise their behaviours to their stakeholders (Hinson et al., 2010). Thus both of these theories are somehow stakeholder driven. 
Finally, the review suggests that there is existing CSR framework for the Malawian quoted companies. In relation to ISO 26000 framework, the Malawian framework explicitly and in much detail covers the subject of organisational governance only. However, the other six core subjects are implicitly covered. They are either broadly mentioned such as environment and community involvement and development or can be implied through the "umunthu" values. The implied subjects include human rights, labour practices, consumer issues and fair operating practices. This kind of inclusion is problematic in that it gives too much discretion to the organisations to decide on what to report, the format, location and depth of the disclosures. This may seriously impact on the quality, visibility and relevance of the CSR reportage.

\section{Research Methodology}

\subsection{Data Collection}

The study focused on the CSR disclosure in the annual reports of the listed companies consistent with other related studies (Popa et al., 2009; Haque \& Deegan 2010; Mbekomize \& Wally-Dima, 2013). In order to evaluate the current status of CSR reporting the study uses the more recent annual reports for the year 2012 and 2013. The population comprised all the companies listed on the Malawi Stock Exchange. As can be seen on Table 1, there were 14 listed companies in 2012 and 2013. However, the sample comprised companies whose primary operating environment was Malawi and whose annual reports and not simple financial statements for 2012 and 2013 were accessible. Eleven (79\%) companies met the criteria thus they formed the sample for the study. The eleven sampled companies were thereafter randomly coded using alphabetical letters of A to K.

Table 1. List of companies listed on MSE and their sectors

\begin{tabular}{cll}
\hline No & Name of the companies & Industry/ Sector \\
\hline $\mathbf{1 .}$ & Blantyre Hotels Limited & Tourism \\
$\mathbf{2 .}$ & First Merchant Bank & Banking \\
$\mathbf{3 .}$ & Illovo Sugar & Agro-processing \\
$\mathbf{4 .}$ & MPICO Limited & Property Development \\
$\mathbf{5 .}$ & National Bank of Malawi & Banking \\
$\mathbf{6 .}$ & NBS Bank & Banking \\
$\mathbf{7 .}$ & NICO Holdings Limited & Financial \\
$\mathbf{8 .}$ & National Investment Trust Limited & Investment Trust \\
$\mathbf{9 .}$ & Press Corporation Limited & Conglomerate \\
$\mathbf{1 0 .}$ & Real Insurance Limited & Insurance \\
$\mathbf{1 1 .}$ & Standard Bank & Banking \\
$\mathbf{1 2 .}$ & Sunbird Tourism Limited & Tourism \\
$\mathbf{1 3}$ & Telekom Networks Limited & Telecoms \\
$\mathbf{1 4 .}$ & Old Mutual Limited & Financial \\
\hline
\end{tabular}

Source: Malawi Stock Exchange.

\subsection{Data Analysis}

Content analysis was used to measure the extent of CSR disclosure consistent with other related studies (Haque \& Deegan 2010; Gao, 2011; Mbekomize \& Wally-Dima, 2013). Content analysis is generally acknowledges as a method that is widely used in the accounting research, particularly in social accounting disclosure studies (Ebimobowei, 2011). The measurements are made using a CSR disclosure index (see Table 2) developed based on the seven core subjects of social responsibility according to ISO 26000 (International Organization for Standardization, 2010). 
Table 2. CSR disclosure index

\begin{tabular}{|c|c|c|c|}
\hline & A. Labour practices & & B. Fair operating practices \\
\hline 1. & Employment and employment relationships & 1. & Anti-corruption \\
\hline 2. & Conditions of work and social protection & 2. & Responsible political involvement \\
\hline 3. & Social dialogue & 3. & Fair competition \\
\hline 4. & Health and safety at work & 4. & Promoting social responsibility in the value chain \\
\hline \multirow[t]{2}{*}{5.} & Human development and training in the workplace & 5. & Respect for property rights \\
\hline & C. Consumer issues & & D. Community involvement and development \\
\hline 1. & $\begin{array}{l}\text { Fair marketing, factual and unbiased information and fair contractual } \\
\text { practices }\end{array}$ & 1. & Community involvement \\
\hline 2. & Protecting consumers' health and safety & 2. & Education and culture \\
\hline 3. & Sustainable consumption & 3. & Employment creation and skills development \\
\hline 4. & Consumer service, support, and complaint and dispute resolution & 4. & Technology development and access \\
\hline 5. & Consumer data protection and privacy & 5. & Wealth and income creation \\
\hline 6. & Access to essential services & 6. & Health \\
\hline \multirow[t]{2}{*}{7.} & Education and awareness & 7. & Social investment \\
\hline & E. Human rights & & F. The environment \\
\hline 1. & Due diligence & 1. & Prevention of pollution \\
\hline 2. & Human rights risk situations & 2. & Sustainable resource use \\
\hline 3. & Avoidance of complicity & 3. & Climate change mitigation and adaptation \\
\hline 4. & Resolving grievances & 4. & $\begin{array}{l}\text { Protection of the environment, biodiversity and } \\
\text { restoration of natural habitats }\end{array}$ \\
\hline 5. & Discrimination and vulnerable groups & & \\
\hline 6. & Civil and political rights & & \\
\hline 7. & Economic, social and cultural rights & & \\
\hline 8. & Fundamental principles and rights at work & & \\
\hline & G. Organizational governance & & \\
\hline 1. & Decision making processes and structures /Corporate governance & & \\
\hline 2. & Ethical behaviour/code of ethics & & \\
\hline 3. & Respect for stakeholders interests & & \\
\hline 4. & Respect for the rule of law & & \\
\hline
\end{tabular}

Source: International Organization for Standardization (2010).

Consistent with Popa et al. (2009); Haque and Deegan (2010), the presence or absence of an item was the measure for the extent of CSR reporting. As it is exhibited on Table 2, there are 79 items of disclosure. All these items on the table were equally weighted as such if the item was disclosed in the annual report, it was awarded a score of " 1 " and if not disclosed a score of "0" is given (Faisal et al., 2012). The index is calculated using the following formula that was employed in Lipunga (2014):

$$
\text { CSR index }=\sum_{j=1} \frac{d j}{n}
$$

Where: $\quad d j=1$ if item $\mathrm{j}$ is disclosed; 0 if item $\mathrm{j}$ is not disclosed

$\mathrm{n}=$ number of items.

In accordance with the formula, the CSR disclosures scores range between the maximum of " 1 " and a minimum of " 0 ". For analysis purposes, the scoring was done in three levels namely: CSR category (subject) score, company score and overall score. Category score represents the average relative disclosure of each of the seven 
core subjects (see Table 2), whereas company score is the relative average score of each of the sampled companies. On the other hand, the overall score represents the average disclosure score for all sampled listed companies, indicating the overall CSR disclosure by the listed companies.

\section{Findings and Discussions}

This section presents the results of analysis and the ensuing discussion. The results are presented at three CSR reporting levels namely: CSR category (subject) level, company level and average (overall) level for all the sampled listed companies. As already discussed, the CSR category levels indicate how each of the seven CSR categories per ISO 26000 were reported in annual reports by the sampled companies. Company CSR level provides the average reporting level of the each of the eleven sampled companies, while the overall level gives the average reporting level of all the sampled companies.

\subsection{CSR Category Level}

Figure 2 presents the results of analysis of the levels of disclosure of each the seven CSR categories of ISO 26000 as disclosed by the sampled listed companies. The figure indicates that the sampled companies disclosed far much better on organisational governance both in year $2012(0.86)$ and $2013(0.82)$ relative to the other six subjects. Generally, the high disclosure score of organisational governance was expected. As already discuss this is the only subject that is provided explicitly and in much detail in the corporate governance code and guidelines. Furthermore, the listed companies are required by listing rules to disclose in their annual financial statements, the extent of their compliance or non-compliance with the code of corporate practices and conduct contained in the Cadbury or King Reports on corporate governance (Malawi Stock Exchange, 2008). These reports also extensively cover the elements of organisational governance. The companies may have reported highly on organisational governance not motivated by CSR obligations, but merely following the listing rules. This may be indicative that where clear regulations or guidelines are given, companies tend to faithfully comply; hence suggesting that in order to enhance CSR reporting there is a need for clear guidelines to ensure high and holistic disclosure of CSR information.

The second highest CSR category score was that of community involvement and development scoring 0.45 in 2012 and 0.48 in 2013. Relative to the scores of organisational governance, the scores exhibits a wide gap that needs to be closed. The third highest was labour practices category scoring 0.36 and 0.45 in 2012 and 2013 respectively. On the other end, Figure 2 shown that the lowest disclosed category was human right that scored 0.05 in 2012 and 0.02 in 2013. Followed by consumer issues category scoring 0.13 and 0.1 in 2012 and 2013 respectively and fair operating practices scoring 0.09 in 2012 and 0.15 in 2013.

Figure 2 exhibits further that the CSR scores the majority of the categories (4) decreased i.e. scores for organisational governance, human rights, environment and consumer issues. On the other hand only scores for three (3) categories improved i.e. scores for labour practices, fair operating practices and community involvement and development. Besides only three categories i.e. organisational governance, labour practices and community involvement and development, had scores of over 0.3 , the rest (4) scored less than 0.3 over the two year period of study. However, as is exhibited on Figure 2, even the three subjects that scored over 0.3 only one (organisational governance) scored over 0.5 , the remaining two (labour practices and community involvement and development) scored less than 0.5 .

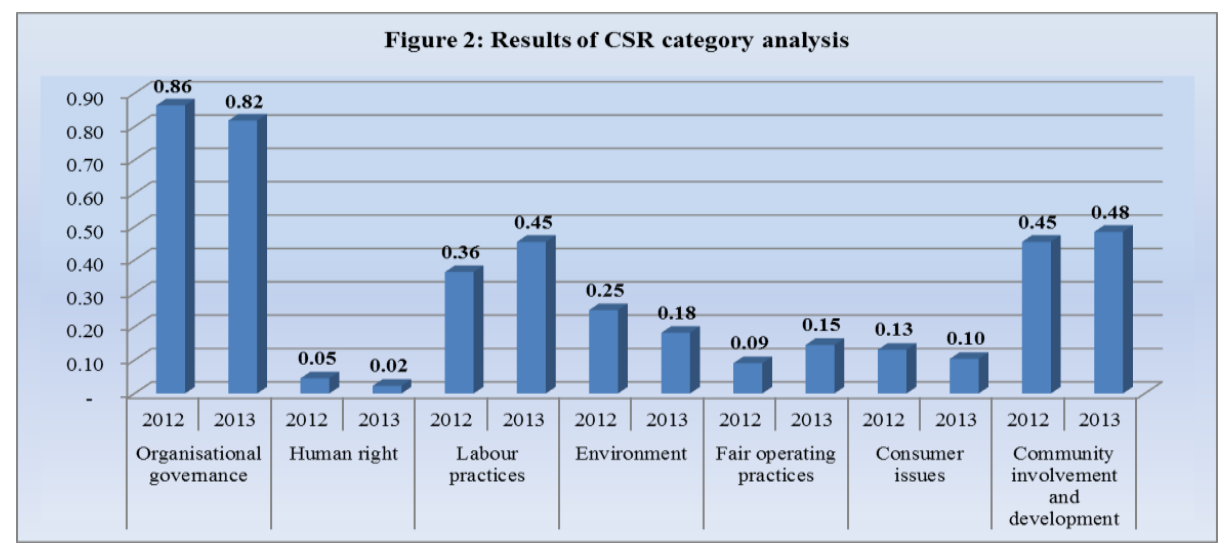

Figure 2. Results of CSR category analysis 
The one result that is worth noting is the low and declining scores of consumer issues i.e. 0.13 and 0.1 in 2012 and 2013 respectively. Consumers are generally considered as the players who justify the existence of the organization (Ávila et al., 2013). This makes them important stakeholders which one would naturally expect a good deal of disclosures in their regard, which is not the case per the result. However, it seems that low customer issues disclosures not to be unique to Malawi; Ávila et al. (2013) also found the same. As a result, Ávila et al. (2013) opined that this apparent lack of disclosure could emanate from the fact that organizations may be more concerned with their images as implementers of the concepts and premises of social responsibility and less interested in undertaking the required actions to ensure implementation. This may be an area of future studies.

The results of analysis of CSR category level scores, indicates that the "umunthu" values that are advocated by the Malawi code of corporate governance are yet to have remarkable impact on CSR reporting by the sampled listed companies in their annual reports. Considering that annual reports are commonly used to signal what is important (April et al. 2003), the results may suggest that preparers of annual reports are yet to realise the significance of the "umunthu" oriented CSR disclosures. May due to the lack of details or guidance in on what it entails in relation to reporting. Thus the results indicate that there is much room for improvement across all the CSR subjects, except perhaps with regard to organisational governance. Promotion ISO 26000 may be ideal in order to promote awareness among the preparers of annual reports relating to CSR holistically. The same may result in the adoption of holistic approach to social responsibility (Ávila et al., 2013). Malawian policy makers and implementers need to consider adoption of the ISO 26000 standard.

\subsection{Company CSR Level}

Figure 3 presents the average CSR reporting scores of each of the eleven sampled companies of the period of the study. For analysis sake, the CSR scores were divided into three levels as follows: (1) those that scored equal to or more than 0.5 , (2) those that scored between less than 0.5 and equal to or more than 0.1 , and (3) those that scored less than 0.1. The divisions were made considering that the overall (average) CSR scores for the sample listed companies in both years under study was constant at 0.3 (see Table 3 below).

Accordingly, as can be observed on Figure 3, only two companies (B and H) managed to score over 0.5 in both 2012 and 2013. The highest in both years being company H scoring 0.54 in 2012 and 0.57 in 2013, followed by company B that scored 0.53 in 2012 and 0.56 in 2013. The results suggest that on average companies B and H disclosed at least half of the disclosable items presented in Table 2 above in their respective annual reports. On the other end, Figure 3 shows that two companies ( $\mathrm{C}$ and $\mathrm{G})$ had scores of less than 0.1. Company $\mathrm{C}$ scored less than 0.1 in both 2012 and 2013, while company G scored less 0.1 in 2012 only. Besides being the lowest scorer, Company C's disclosure scores declined in 2013, this should be a cause of concern.

Majority of the companies i.e. seven (7) in 2012 and eight (8) in 2013 scored on the middle category (i.e. between less than 0.5 and equal to or more than 0.1 ). Out of the seven in 2012, four scored over 0.3 (i.e. the overall average) and in 2013 out of the eight, four again scored over 0.3. As can be observed company D registered improvement from a below average score of 0.28 to the above average of 0.32 , whereas company K's level of CSR reporting declined from the above average score of 0.35 in 2012 to a below average score 0.22 in 2013. The results indicate that a slim majority of the sampled companies (i.e. six in both years) scored above average. Again the results indicate that a slim majority of the companies (i.e. six) improved their CSR score.

The results of analysis of the CSR Company scores suggest that all the sampled companies are disclosing some CSR information, however only two are disclosing at least half of the disclosable items according to the CSR disclosure index. This indicates that much more effort is needed by each of the companies. Furthermore, the results shows that although the majority of the companies improved their scores, the improvements were marginal; besides a good number of the companies (i.e. 4 companies) registered decreasing scores in 2013 relative to 2012 scores. This has generally resulted in the overall CSR score remaining constant (see Table 3). Thus the promotion of CSR reporting is needed in all the sampled companies. 


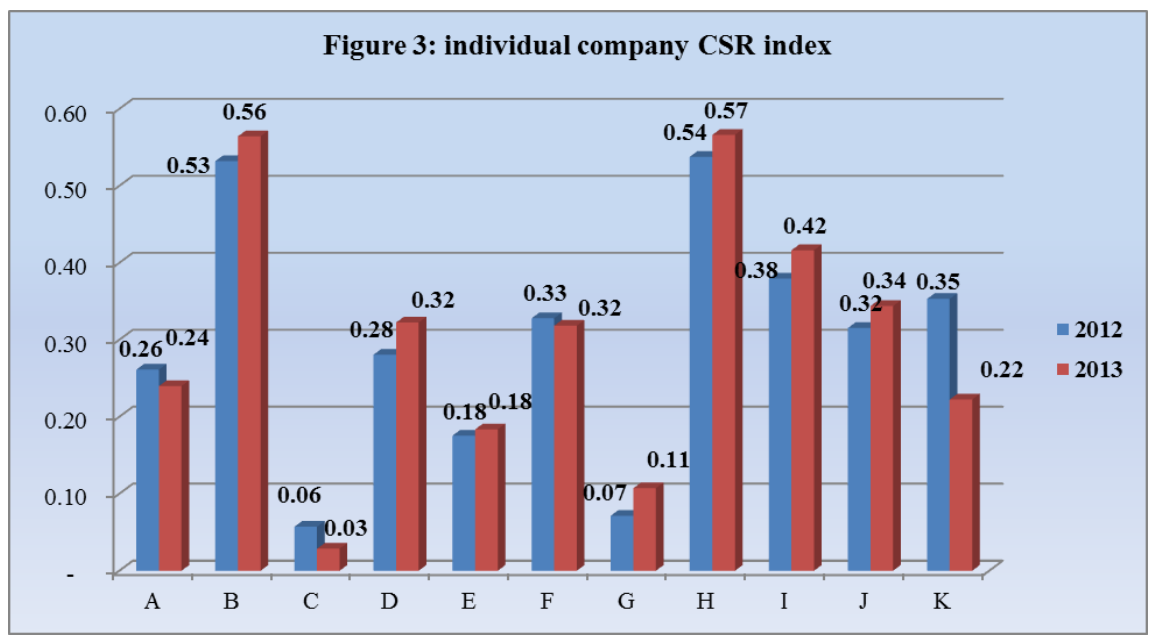

Figure 3. Individual company CSR index

\subsection{Overall CSR Level}

Table 3 presents the overall scores for the 2012 and 2013. The scores represent the average disclosure level for the sample listed companies, which gives idea of the average reporting gap. As is exhibited on the Table, the overall score remained constant $(0.3)$ over the two years. The scores indicate that on average, the sampled quoted companies disclosed only 30\% of the disclosable items presented in Table 2 above in both 2012 and 2013. This gives a CSR reporting gap of 0.6 [i.e. the maximum score (1) minus the actual score (0.3)] that needs filling. The wide reporting gaps were also found in two prior CSR disclosure studies relating to the Malawian commercial banks sector. Lipunga (2014) found an overall score of online CSR reporting (0.14) and (0.4) for CSR reporting in the annual reports. Lipunga (2013) also found an overall CSR score of (0.3) for disclosures in the annual reports. These studies may be suggestive that low CSR reporting in a general problem amongst Malawian organisations. Thus the researcher recommends a more comprehensive study with bigger sample.

On the other hand, the overall CSR scores show the current status of CSR reporting in line with ISO 26000. Considering that the standard has not been generally promoted and hence not well known in the country, the study suggests that the promotion may not face serious challenges as the companies are already disclosing CSR information to some extent. The study thus gives impetus to the policy makers by highlighting the existing gaps. This may act as a launching pad for ISO 26000 promotion programmes.

Table 3. Overall level of CSR reporting

\begin{tabular}{ccc}
\hline Year & CSR Index (Average) & Standard Deviation \\
\hline $\mathbf{2 0 1 2}$ & 0.30 & 0.16 \\
$\mathbf{2 0 1 3}$ & 0.30 & 0.17 \\
\hline
\end{tabular}

\section{Conclusion}

The purpose of the study was to evaluate the extent of CSR reporting by the Malawian listed companies in their annual reports through the lens of ISO 26000 - Guidance on social responsibility. This was in recognition of the importance of CSR and CSR reporting in the current new economy. The results provide empirical evidence of CSR reporting among Malawian quoted companies. Based on the CSR reporting scores, the results highlight that although all the sampled companies are disclosing CSR information in their annual reports; the level of disclosure is low and has being constant at 0.3 in 2012 and 2013. Furthermore the companies had placed relatively greater emphasis in reporting on organisational governance information only, with score of over 0.8 . The other CSR subjects that scored better were community involvement and development and labour practices; however the scores were less than 0.5. On the other hand, human rights, consumer issues, fair operating practices and the environment scored poorly. Furthermore the results showed that only two companies out of the eleven that were sampled disclosed at least half of the disclosable items. Thus the study reveals existence of a wide CSR reporting gap amongst the sampled listed companies consistent with prior studies in among the Malawian commercial banks (Lipunga, 2013; Lipunga, 2014). Furthermore the study provides evidence of the extent to 
which the CSR reporting is in line with ISO 26000. Scientifically the study contributes to CSR reporting literature from developing countries where currently little is known of (Gao, 2011), and specifically from Malawi.

The limitations of the study include the fact that it did not measure the quality of the CSR disclosures in the annual reports. Future studies should consider examining not only the quantity but also the quality and depth of the disclosures. Furthermore the study measured the reporting levels for two years only. Future studies should considered examining CSR reporting take a longer period, in order to provide a comprehensive map of organizations' progress in implementing social responsibility initiatives (Ávila et al., 2013). Finally the study examined only the quoted companies, thus the results may not be generalizable. Future research should consider enlarging the sample to include non-quoted companies.

\section{References}

Abbasi, T. H., Kausar, A., Ashiq, H., Inam, H., Nasar, H., \& Amjad, R. (2012). Corporate social responsibility disclosure: a comparison between Islamic and conventional financial institutions in Bahawalpur Region. Research Journal of Finance and Accounting, 3, 51-61.

Akinpelu, Y. A., Ogunbi, O. J., Olaniran, Y. A., \& Ogunseye, T. O. (2013). Corporate social responsibility activities disclosure by commercial banks in nigeria. European Journal of Business and Management, 5(7). Retrieved from http://www.iiste.org/Journals/index.php/EJBM/article/view/4716

Al-Khater, K., \& Naser, K. (2003). Users' perceptions of corporate social responsibility and accountability: Evidence from an emerging economy. Managerial Auditing Journal, 18(6), 538-548. http://dx.doi.org/10.1108/02686900310482678

April, K. A., Bosma, P., \& Deglon, D. A. (2003). IC measurement and reporting: Establishing a practice in SA mining. Journal of Intellectual Capital, 4, 165-180. http://dx.doi.org/10.1108/14691930310472794

Ávila, L. V., Hoffmann, C., Corrêa, A. C., Madruga, L. R. D. G., Júnior, V. F. S., Júnior, A. F. D. S., \& Zanini, R. R. (2013). Social responsibility initiatives using ISO 26000: An analysis from Brazil. Environmental Quality Management, Winter 2013, 15-30. http://dx.doi.org/10.1002/tqem.21362

CAMAC. (2006). Discussion paper: Corporate social responsibility. Retrieved from http://www.camac.gov.au/camac/camac.nsf/byHeadline/PDFSubmissions_2/\$file/ABA_CSR.pdf.

Castka, P., \& Balzarova, M. A. (2007). A pathway to 'CSR excellence': The roles of ISO 9000 and ISO 26000 12-ICIT 9-11/4/07 in RoC going for gold quality standards: ISO 9000, etc. Paper \#: 02-05, pp. 1-6 Retrieved form http://www.bm.nsysu.edu.tw/tutorial/iylu/12th\%20ICIT/02-05.pdf

Castka, P., \& Balzarova, M. A. (2008). Social responsibility standardization: Guidance or reinforcement through certification? Human Systems Management, 27(2008), 231-242.

Ebimobowei, A. (2011). A study of social accounting disclosures in the annual reports of Nigerian companies. Asian Journal of Business Management, 3(3), 145-151. Retrieved from http://maxwellsci.com/print/ajbm/v3-145-151.pdf

Faisal, F., Tower, G., \& Rusmin, R. (2012). Legitimising corporate sustainability reporting throughout the world. Australasian Accounting Business and Finance Journal, 6(2), 2012, 19-34. Retrieved from http://ro.uow.edu.au/aabfj/vol6/iss2/3

Frynas, J. G. (2012). Corporate social responsibility or government regulation? Evidence on oil spill prevention. Ecology and Society, 17(4), 4. http://dx.doi.org/10.5751/ES-05073-170404

Gao, Y. (2011). CSR in an emerging country: A content analysis of CSR reports of listed companies. Baltic Journal of Management, 6(2), 263-291. http://dx.doi.org/10.1108/17465261111131848

Habidin, N. F., Fuzi, N. M., Desa, A. F. N. C., Hibadullah, S. N., \& Zamri, F. I. M. (2012). Corporate Social Responsibility Practices (CSRP) and ISO 26000 performance efforts in Malaysian automotive industry. International Journal of Economics, Finance and Management, 1(1), 1-7. Retrieved from http://www.academia.edu/7006433/Corporate_Social_Responsibility_Practices_CSRP_and_ISO_26000_Pe rformance_Efforts_in_Malaysian_Automotive_Industry._International_Journal_of_Economics_Finance_an d_Management_1_1_1-7

Haque, S., \& Deegan, C. (2010). Corporate climate change-related governance practices and related disclosures: Evidence from Australia. Australian Accounting Review, 55(20), 317-333. http://dx.doi.org/10.1111/j.1835-2561.2010.00107.x 
Hayes, J. K., \& Ebinger, C. K. (2011). The Private Sector and the Role of Risk and Responsibility in Securing the Nation's Infrastructure. Journal of Homeland Security and Emergency Management, 8(1). http://dx.doi.org/10.2202/1547-7355.1597

Hernáez, O., Zugasti, I., Waltersdorfer, G., Matev, D., Assenova, M., Jonkute, G...., Aranda, J. (2012). Corporate social responsibility on SMEs. 15th European roundtable on sustainable consumption and production (15th ERSCP), May 2-4, Bregenz, Austria. Retrieved from http://vbn.aau.dk/files/66744278/Corporate_Social_Responsibility_on_SMEs.pdf

Hinson, R., Boateng, R., \& Madichie, N. (2010). Corporate social responsibility activity reportage on bank websites in Ghana. International Journal of Bank Marketing, 28(7), 498-518. http://dx.doi.org/10.1108/02652321011085176

Institute of Directors of Malawi. (2010). The Malawi code II: Code of best practice for corporate governance in Malawi, overarching provisions. Retrieved from http://www.ecgi.org/codes/documents/malawi_codeii_1jun2010_en.pdf

Institute of Directors of Malawi. (2011). The Malawi code II: Code of best practice for corporate governance in Malawi, sector guidelines for listed companies. Retrieved from http://www.ecgi.org/codes/documents/sector_guidelines_listed_companies_malawi_10feb2011_en.pdf

International Organization for Standardization. (2010). Discovering ISO 26000. Retrieved from http://www.iso.org/iso/discovering_iso_26000.pdf

Karagiorgos, T. (2010). Corporate social responsibility and financial performance: An empirical analysis on greek companies. European Research Studies, XIII(4), 85-108. Retrieved from http://www.ersj.eu/repec/ers/papers/10_4_p6.pdf

Khan, H., \& Ali, M. (2010). An empirical investigation and users" perceptions on intellectual capital reporting in banks: Evidence from Bangladesh. Journal of Human Resource Costing and Accounting, 14(1), 48-69. http://dx.doi.org/10.1108/14013381011039799

Khomba, J. K., \& Vermaak, F. N. S. (2012). Business ethics and corporate governance: An African socio-cultural framework. African Journal of Business Management, 6(9), 3510-3518.

Lee, S. (2005). Implementing corporate social responsibility in health sector. MBA dissertation, China Europe International Business School, 699, Hong Feng Road, Pudong, Shanghai, People's Republic of China. Retrieved from http://www.ceibs.edu/bmt/images/20081103/13532.pdf

Lipunga, A. M. (2013). Corporate social responsibility reporting by commercial banks in annual reports: Evidence from Malawi. International Journal of Business and Social Research, 3(9), 88-101. Retrieved from http://thejournalofbusiness.org/index.php/site/article/view/258/295

Lipunga, A. M. (2014). Web-based corporate social responsibility information disclosure by Malawian commercial banks. IOSR Journal of Business and Management (IOSR-JBM), 16(4), 08-15. http://dx.doi.org/10.9790/487X-16420815

Malawi Stock Exchange. (2008). Listing requirements. Retrieved from http://mse.co.mw/rules/MALAWI\%20STOCK\%20EXCHANGE\%20LISTING\%20REQUIREMENTS.pdf

Masud, M. A. K. (2011). CSR practices of private commercial banks in Bangladesh. Retrieved from http://mpra.ub.uni-muenchen.de/35496/

Mbekomize, C. J., \& Wally-Dima, L. (2013). Social and environmental disclosure by Parastatals and companies listed on the Botswana stock exchange. Journal of Management and Sustainability, 3(3), 66-75. http://dx.doi.org/10.5539/jms.v3n3p66

Mohammed, R., Alwi, K., \& Jamil, C. Z. M. (2009). Sustainability disclosure among Malaysian Shari'ah-Compliant listed companies: Web reporting. Issues in Social and Environmental Accounting, 3(2), $160-179$.

Retrieved

from http://www.researchgate.net/publication/258424035_Sustainability_Disclosure_among_Malaysian_Shari\% 27ah-Compliant_listed_Companies_Web_Reporting

Popa, A., Blidişel, R., \& Bogdan, V. (2009). Transparency and disclosure between theory and practice: A case study of Romania. Retrieved from http://kgk.bmf.hu/fikusz

Reserve Bank Malawi. (2010). Corporate governance guidelines. Retrieved from: http://www.rbm.mw/documents/basu/Corporate\%20Governance\%20Guidelines.pdf 
Roberts, J. M. (May 3, 2010). How corporate social responsibility (ISO 26000) mandates undermine free markets, backgrounder, No. 2409, May 3, 2010. Retrieved from http://www.heritage.org/research/reports/2010/05/corporate-social-responsibility-standards-iso-26000-bad-f or-business

Sitnikov, C. S., \& Bocean, C. G. (2012). Corporate social responsibility through the lens of ISO standards. Business Excellence and Management, 2(4), 56-66. Retrieved from http://beman.ase.ro/no24/6.pdf

Smeureanu, I., Dioşteanu, A., Delcea, C., \& Cotfas, L. (2011). Business ontology for evaluating corporate social responsibility. Amfiteatru Economic, XIII(29), 28-42. Retrieved from http://www.amfiteatrueconomic.ro/temp/Article_1012.pdf

Tjia, O., \& Setiawati, L. (2012). Effect of CSR disclosure to value of the firm: Study for banking industry in Indonesia. World Journal of Social Sciences, 2, 169-178. Retrieved from http://www.wjsspapers.com/static/documents/September/2012/13.\%20Lulu1.pdf

United Nations Environment Programme. (2011). Corporate social responsibility and regional trade and investment agreements. Retrieved from http://www.unep.ch/etb/publications/CSR\%20publication/UNEP_Corporate\%20Social\%20Responsibility.p $\mathrm{df}$

Ward, H. (2012). ISO 26000 and global governance for sustainable development. International Institute for Environment and Development. London. Retrieved from http://pubs.iied.org/pdfs/16507IIED.pdf

Yeshmin, F. (2012). Visualization of corporate social responsibility information of commercial bank in Bangladesh. World Journal of Social Sciences, 2(5), 114-127. Retrieved from http://www.wbiconpro.com/610-Farjan.pdf.

Yeung, S. (2011). The role of banks in corporate social responsibility. Journal of Applied Economics and Business Research, 1(2), 103-115. Retrieved from http://www.aebrjournal.org/uploads/6/6/2/2/6622240/4.shirley.pdf

Zhang, W. (2012). Gap analysis of ISO 26000 in two Atlas Copco Companies in China: Atlas Copco (Nanjing) Construction and Mining Equipment Co., Ltd. and Wuxi Pneumatech Air/ Gas Purity Equipment Co., Ltd. MSc Thesis, Stockholm 2012, Industrial Ecology, Royal Institute of Technology. Retrieved from http://www.diva-portal.org/smash/get/diva2:513915/FULLTEXT01.pdf

\section{Copyrights}

Copyright for this article is retained by the author(s), with first publication rights granted to the journal.

This is an open-access article distributed under the terms and conditions of the Creative Commons Attribution license (http://creativecommons.org/licenses/by/3.0/). 